\section{BST gets clean bill of health}

\section{Washington}

MILK and meat derived from cows treated with a synthetic version of bovine somatotropin, otherwise known as growth hormone, are safe for human consumption.

But despite the approval from experts at a National Institutes of Health (NIH) technology assessment conference last week, the more than five years of controversy surrounding bovine somatotropin is unlikely to end here. The drug has yet to be approved for commercial use by the US Food and Drug Administration (FDA) and the outcome of several investigations into scientific misconduct involving FDA and the drug companies are still pending.

Turning up the heat on the issue last week, the Consumer Policy Institute (CPI) released a report entitled Biotechnology and Milk: Benefit or Threat that called on the FDA to halt the sale of milk from cows being experimentally treated with rbST, which FDA approved in 1985 , while re-evaluating the impact of rbST on human health. CPI's report was met with an immediate rebuttal by the American Farm Bureau Federation (AFBF), the largest farm organization in the United States.

Despite the reluctance of NIH to become involved in regulatory matters, NIH convened the ad hoc 13-member panel of medical and veterinary experts at the behest of Congress.

The NIH panel concluded that the overall nutritional composition and quality of milk and meat from rbST-treated cows is equal to that of untreated cows and that the health of dairy cows is not appreciably affected. Acknowledging that some animal trials showed evidence of an increased incidence of mastitis, the panel

\title{
Networks spur to crime
}

\section{Washington}

THE dizzying growth of computer networks in the past decade has meant gaping security holes, primitive software protection and general disregard of the threat of computer crime, warns a report from the US National Academy of Sciences (NAS), published last week*

Rather than being exceptional, the well-publicized cases of computer virus, break-ins and fraud that have captured headlines over the past few years are just the exposed tip of a growing computer security problem.

"So far, the nation has been remarkably lucky in escaping any successful systematic attempts to subvert critical computing systems", says David Clark of the Massachusetts Institute of Technology who headed the independent NAS panel. "Unfortunately, there is reason to believe that our luck may soon run out unless we take action now."

Systematic or not, the examples cited by the report are sobering: A \$259-million fraud in which staff at the car company Volkswagen reprogrammed computers to show false currency exchange transactions; an "almost-successful" attempt to defraud the Pennsylvania lottery out of $\$ 15.2$ million by breaking into a database of unclaimed winning tickets; and a foiled attempt to make and use thousands of automatic teller machine cards with personal identification numbers pirated from an online database.

The NAS panel calls for the creation of a non-profit consortium of computer users, manufacturers and others in the computer industry to research computer

* Computers at Risk, National Academy Press, 1991. security, track computer crime and promote adherence to an industry-wide set of security standards. The Information Security Foundation could operate on a \$15-\$20 million annual budget with funding provided by its members, NAS suggests.

Apathy and misguided trust are the

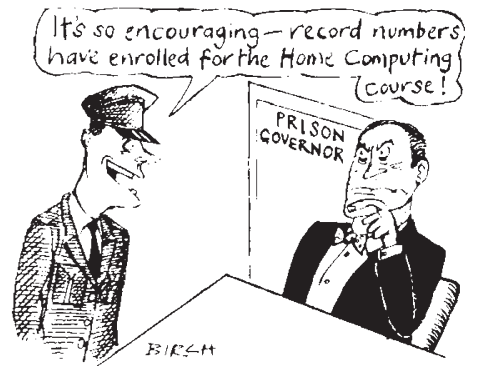

most serious obstacles to improved security practices, the report says. "It is as if a small town were to wake up one day to find that it had turned into a metropolis, yet everyone continued to leave their houses and cars unlocked based on blind faith in a past reality", says Clark. Much of the computer security now practised is carried out only so as to meet government regulations, he noted. And although some computer manufacturers are planning to adopt new protection techniques, others are reluctant to include security features - at extra cost and trouble - without greater customer demand.

But if US industry does not adapt common security standards soon, it may find it increasingly difficult to compete in the European market, where the European Communities are likely to set continentwide guidelines for data protection, the report warns.

Christopher Anderson could not rule out the possibility that this might lead to an increased use of antibiotics and, thus increased antibiotic residues in milk.

During the lively scientific debate, panel members listened to disquieting claims, made by several speakers, of intimidation by drug companies and attempts by them and the FDA to suppress and manipulate animal health data on rbST. David Kronfeld, veterinarian at the Virginia Polytechnic Institute, said that he tried unsuccessfully to obtain sponsorship from two drug companies to study possible stress parameters in rbST-treated cows. University scientists are chosen Kornfeld said, "if they belong to the persuasion that rbST can have no adverse effects". Kornfeld also spoke of letters recently sent to the dean of his institute from a company scientist, which stated that he [Kornfeld] "should not be allowed to speak on bST, or that company would not give money to Virginia Tech".

Samuel Epstein, outspoken critic of rbST and professor of occupational and environmental medicine at the University of Illinois, called the panel's findings a "whitewash". Epstein alleges that confidential drug company research data in his possession clearly demonstrate that cows treated with $\operatorname{rbS} T$ experience reproductive and general health problems, details of which, Epstein claims, do not appear in the published scientific literature. These allegations have prompted the House Committee on Government Operations to initiate an investigation of FDA by the Inspector General of the Department of Health and Human Services.

Diane Gershon

\section{KECK TELESCOPE}

\section{Mirror design success}

\section{San Francisco}

THE innovative segmented-mirror design of the partially completed Keck Telescope has handily passed its first crucial test, say

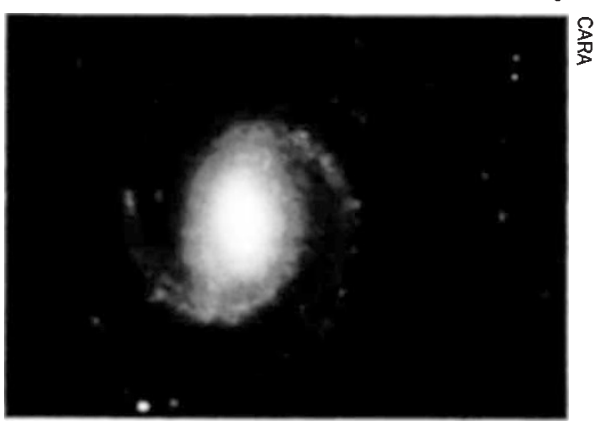

its developers at the California Association for Research in Astronomy (CARA). The group hailed this "first-light" photograph of spiral galaxy NGC 1232 produced by the telescope on 24 November as evidence of the viability of the expensive and previously untried technology.

Elizabeth Schaefer 